\section{Three little known reptile species from the Araku Valley, Eastern Ghats with notes on their distribution}

\author{
Basundhara Chettri ${ }^{1} \&$ S. Bhupathy ${ }^{2}$ \\ 1,2 Sálim Ali Centre for Ornithology and Natural History, Anaikatti \\ (PO), Coimbatore, Tamil Nadu 641108, India \\ Present Address: ${ }^{1}$ Department of Zoology, Sikkim Government \\ College, Tadong, Gangtok, Sikkim 737102, India \\ Email: ${ }^{1}$ basundharac@gmail.com, ${ }^{2}$ bhupathy.s@gmail.com \\ (corresponding author)
}

The Eastern Ghats represent broken and isolated hills of the Deccan Plateau, unlike the continuous mountain range of Western Ghats of the southwestern India. These hills $\left(11^{\circ} 03^{\prime}-22^{\circ} 03^{\prime} \mathrm{N}\right.$ \& $\left.77^{\circ} 02^{\prime}-87^{\circ} 02^{\prime} \mathrm{E}\right)$ extend over $1750 \mathrm{~km}$ from south of the Chota-Nagpur Plateau, Orissa to the southwestern Peninsula in Tamil Nadu (Mani 1974). They are included under 6C Eastern Highlands of the Deccan Plateau, one of the biologically richest Biogeographic Zones of India (Rodgers et al. 2008). Unlike the Western Ghats, studies on the distribution of reptiles in the Eastern Ghats are scanty (Daniels \& Ishwar 1994; Daniels \& Kumar 1998; Bauer \& Das 1999). In the present paper, we provide distribution data for three little known species of reptiles, namely Hemiphyllodactylus aurantiacus, Calodactylodes aureus and Uropeltis ellioti based on two rapid surveys in the Araku Valley, Andhra

Date of publication (online): 26 July 2010

Date of publication (print): 26 July 2010

ISSN 0974-7907 (online) | 0974-7893 (print)

Editor: Aaron Bauer

Manuscript details:

Ms \# 02329

Received 09 October 2009

Final revised received 12 May 2010

Finally accepted 06 June 2010

Citation: Chettri, B. \& S. Bhupathy (2010). Three little known reptile species from the Araku Valley, Eastern Ghats with notes on their distribution. Journal of Threatened Taxa 2(8): 1109-1113.

Copyright: (c) Basundhara Chettri \& S. Bhupathy 2010. Creative Commons Attribution 3.0 Unported License. JoTT allows unrestricted use of this article in any medium for non-profit purposes, reproduction and distribution by providing adequate credit to the authors and the source of publication.

Acknowledgements: The present work was supported by the JSW of Visakhapatnam and Andhra Pradesh Forest Department. We thank P.A. Azeez, Director, SACON for various help and encouragements. Inhabitants of Araku Valley, especially Raj, Raju, Somesh and Kutty were highly helpful. Ranjini and Nikhil of SACON helped us in various ways and A. Pragatheesh of the Wildlife Institute of India, Dehra Dun and Suganthan R. Sakthivel of the Kerala Forest Research Institute, Peechi helped us in preparing the map.

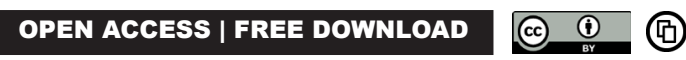

Pradesh and data collected from the literature.

Materials and Methods: The present study was conducted in the Araku Valley (18² $1^{\prime} \mathrm{N} \& 82^{\circ} 56$ 'E, Fig.

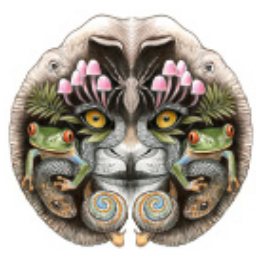
1), Visakhapatnam District, Andhra Pradesh. Vegetation around the Araku Valley is largely tropical moist deciduous forests, with hilltops dominated by Phoenix sp. scrubs and foothills by (coffee) plantations. Khondalite and charkonite group of rocks along with exposed laterite and bauxite are characteristic features of hilltops. The altitude of these hills ranges from 900 to $1400 \mathrm{~m}$. Monthly mean maximum temperature of the area varies from $10^{\circ} \mathrm{C}$ (December) to $37.8^{\circ} \mathrm{C}$ (May) and annual rainfall ranges between 10002000 mm (Rao \& Kumari 2002).

The present report is based on two surveys during 3-10 December 2006 and 16-19 February 2007. During this period, two personnel surveyed the area from 0800 to $1600 \mathrm{hr}$ examining microhabitats such as boulders, crevices, fallen logs, buttress and roots. Reptiles observed during this study were photographed, identified to species level following Smith $(1935,1943)$, Rajendran (1985), and Whitaker \& Captain (2004) and the specimens were released at their original collection sites. The nomenclature followed herein is that of Das (2003). Snout vent length (SVL) and tail length (TL) of selected species were measured using twine and a metal ruler.

Results and Discussion: In all, 16 taxa of reptiles (10 lizard and 6 snake species) were observed in 12 days of survey during 3-10 December 2006 and 16-19 February 2007. Four lizard families, namely Gekkonidae (with five taxa: Hemidactylus brookii, Hemidactylus sp., Geckoella sp. Calodactylodes aureus, Hemiphyllodactylus aurantiacus), Scincidae (Eutropis sp., Lygosoma sp.), Agamidae (Calotes versicolor, Psammophilus sp.) and Varanidae (Varanus bengalensis) were observed during this investigation. Four families of snakes, namely Typhlopidae (Ramphotyphlops braminus), Uropeltidae (Uropeltis ellioti), Colubridae (Liopeltis calamaria, Lycodon travancoricus, Ptyas mucous) and Elapidae (Naja naja) were also observed. Distribution data for three little known species, Hemiphyllodactylus aurantiacus, Calodactylodes aureus and Uropeltis ellioti are given below (Table 1).

Hemiphyllodactylus aurantiacus (Beddome, 1870)

Three specimens of Hemiphyllodactylus were observed on hilltops (1400m). Based on the reduced number (2) of paired lamellae beneath the $4^{\text {th }}$ toe, bolder dorsal patterns, brighter orange-red tail ventrally and males possessing nine preanal pores, these specimens were identified as Hemiphyllodactylus aurantiacus (Images 1-2). All individuals were observed under boulders on the plateau dominated by Phoenix sp. Based on SVL (25.98-28.47 $\mathrm{mm}$ ) and TL (23.58-25.45 mm), these individuals were considered as juveniles, as specimens with SVL (32.38- 


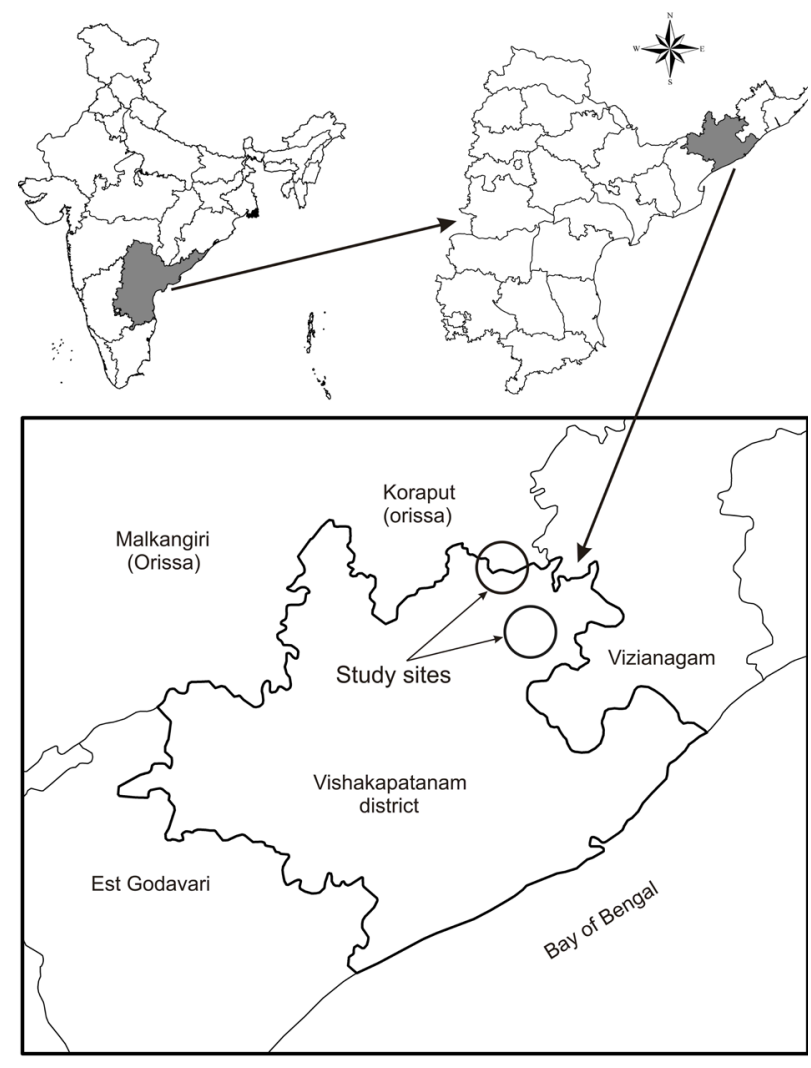

Figure 1. Map showing general location of the Araku Valley and intensive survey areas

$35.2 \mathrm{~mm}$ ) were reported as adults by Bauer \& Das (1999).

Smith (1935) retained the Indian form as a subspecies; Hemiphyllodactylus typus aurantiacus. Bauer \& Das (1999) elevated this to species (Hemiphyllodactylus aurantiacus) and considered it endemic to the Eastern and southern Western Ghats. Including the present record, this species is known from at least ten locations (Fig. 2): Nilgiris, Anaikatty and Anaimalai Hills in Western Ghats, Shevaroy, Kolli (Smith, 1935; Daniels \& Kumar 1998; Bauer \& Das 1999; Mukherjee 2007) and Araku Valley in the Eastern Ghats (present study) and Bangalore (Daniels 1994). It has also been found in the High Wavy Mountains of Theni Forest Division, Tamil Nadu (N. Sathish Kumar, pers. comms.). Recently, this species has been reported from Araku Town, Visakhapatnam District, Maredumilly, West Godavari District and Gundla Brahmeswaram Metta Wildlife Sanctuary, Prakasham District all in the state of Andhra Pradesh (Javed et al. 2010). The report from the Araku Valley is an extension of about $700 \mathrm{~km}$ northeast of Bengaluru (Daniels 1994; Bauer \& Das 1999). We presume that this species is distributed in the intervening areas as well (Fig. 2). Though Sanyal et al. (1993) reported it from the Araku Valley, Bauer \& Das (1999) only speculated its distribution in Andhra Pradesh. Currently, the known altitudinal distribution of this species is 600 to $1400 \mathrm{~m}$. The present report confirms the occurrence of this species in the Araku Valley, and suggests further surveys to know the extent of its distribution both in the Eastern and Western Ghats.

\section{Calodactylodes aureus (Beddome, 1870)}

Two specimens of Calodactylodes aureus were recorded from the rock crevices found near Shova village $\left(18^{\circ} 15^{\prime} \mathrm{N} \& 83^{\circ} 00^{\prime} \mathrm{E}\right)$ in Araku Valley. The area $(970 \mathrm{~m})$ had riverine forest, which was dominated by tree species such as Pongamia glabra, Mangifera indica and Tamarindus indica. The presence of large trapezoid scales organized in a ladder like fashion, one at the base and the other at the free extremity of the terminal phalanx (Smith 1935; Bauer \& Das 2000) identify these specimens as Calodactylodes aureus (Images 3-4). Beddome (1870), Smith (1935) and Javed et al. (2007) reported that both preanal and femoral pores were absent in males. However, Bauer \&

Table 1. Distributional records for Hemiphyllodactylus aurantiacus, Calodactylodes aureus and Uropeltis ellioti.

\begin{tabular}{|c|c|c|c|}
\hline \multirow[b]{2}{*}{ Location } & \multicolumn{3}{|c|}{ Species } \\
\hline & $\begin{array}{c}H . \\
\text { aurantiacus }\end{array}$ & C. aureus & U. ellioti \\
\hline \multicolumn{4}{|l|}{ Tamil Nadu } \\
\hline Vellur & - & + & - \\
\hline South Arcot & - & - & + \\
\hline Jolarpet & - & - & + \\
\hline Shevaroy & + & - & + \\
\hline Kolli Hills & + & - & + \\
\hline Anaikatti Hills & + & - & + \\
\hline Nilgiris & + & - & + \\
\hline Anamalai Hills & + & - & - \\
\hline Manjolai & - & - & + \\
\hline Courtallum & - & - & + \\
\hline High Wavy Mountains & + & - & + \\
\hline \multicolumn{4}{|l|}{ Karnataka } \\
\hline Bangalore & + & - & - \\
\hline Castle Rock & - & $? ?$ & - \\
\hline Goa & - & - & + \\
\hline \multicolumn{4}{|l|}{ Andhra Pradesh } \\
\hline Tirupati Hills & - & + & - \\
\hline Papikonda Hills & - & + & - \\
\hline Maredumilly & + & - & - \\
\hline $\begin{array}{l}\text { Gundla } \\
\text { Brahmeswaram Metta } \\
\text { Wildlife Sanctuary }\end{array}$ & + & - & - \\
\hline Araku Valley & + & + & + \\
\hline \multicolumn{4}{|l|}{ Orissa } \\
\hline Rayagada & - & + & - \\
\hline Kalahandi & - & + & - \\
\hline
\end{tabular}

+ = Present; - = Absent; ?? = Doubtful; see text for authority of records. 


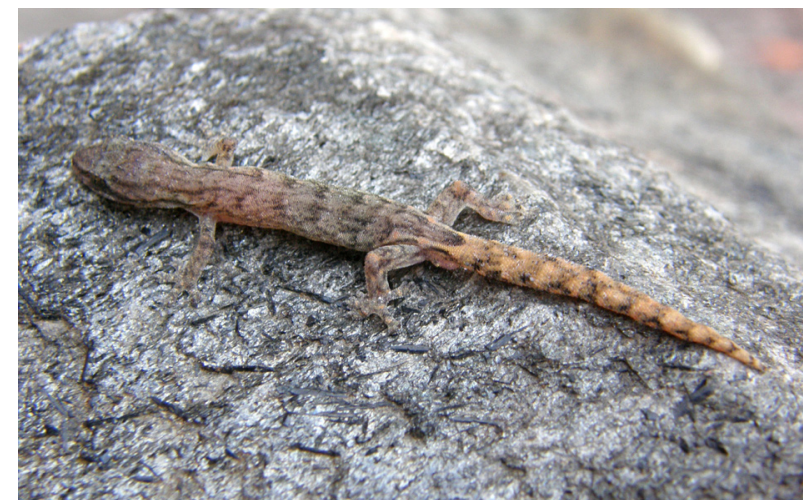

Image 1. Hemiphyllodactylus aurantiacus - dorsal and dorsolateral view

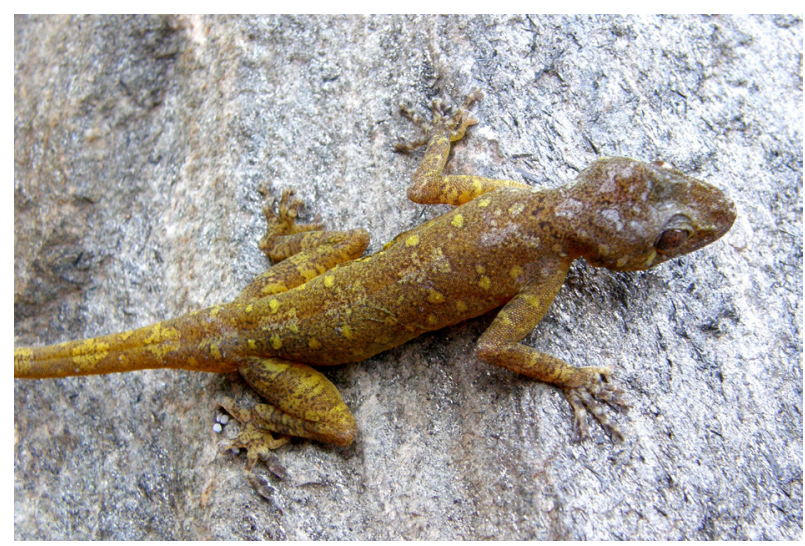

Image 3. Calodactylodes aureus - dorsal view

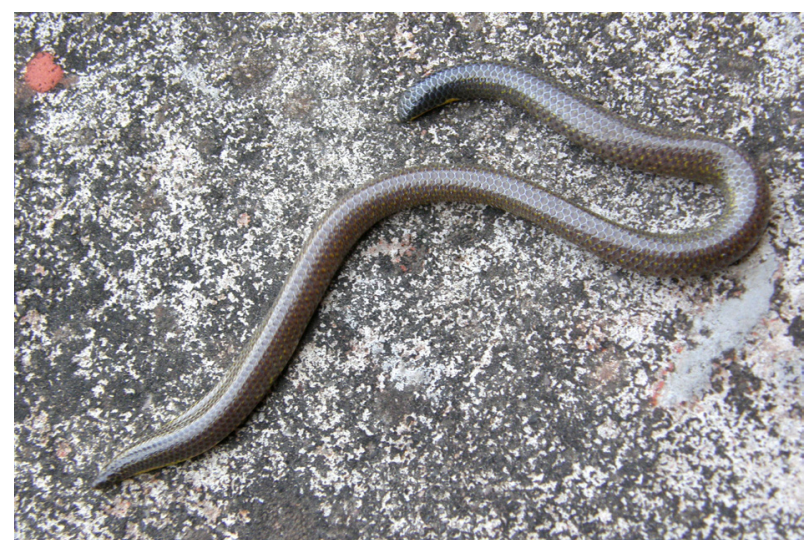

Image 5. Uropeltis ellioti - full view

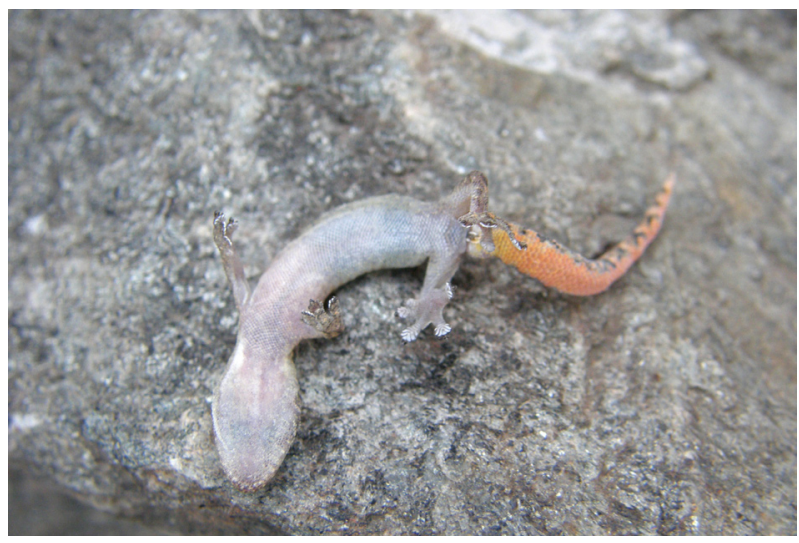

Image 2. Hemiphyllodactylus aurantiacus - ventral view

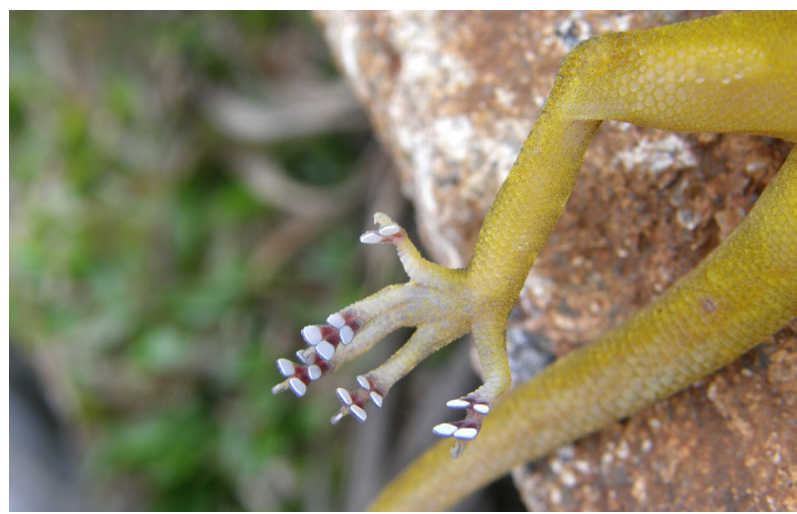

Image 4. Calodactylodes aureus - ventral view of a portion of hind leg and tail

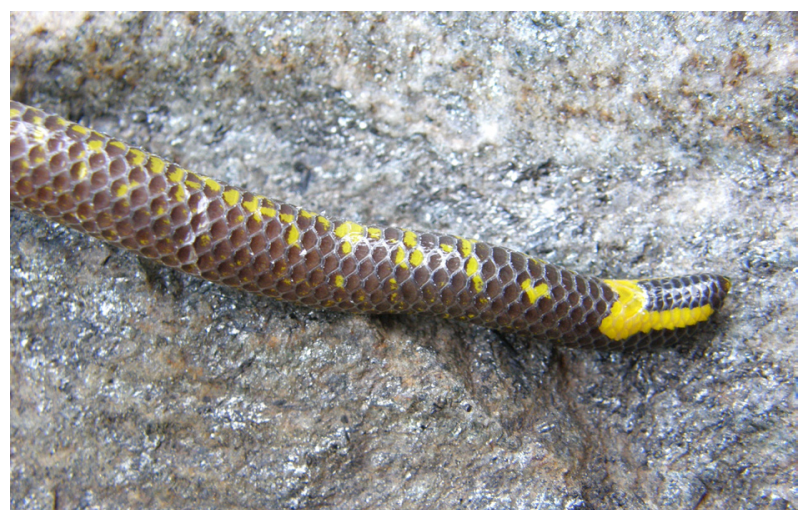

Image 6. Uropeltis ellioti - ventral view of the posterior portion 


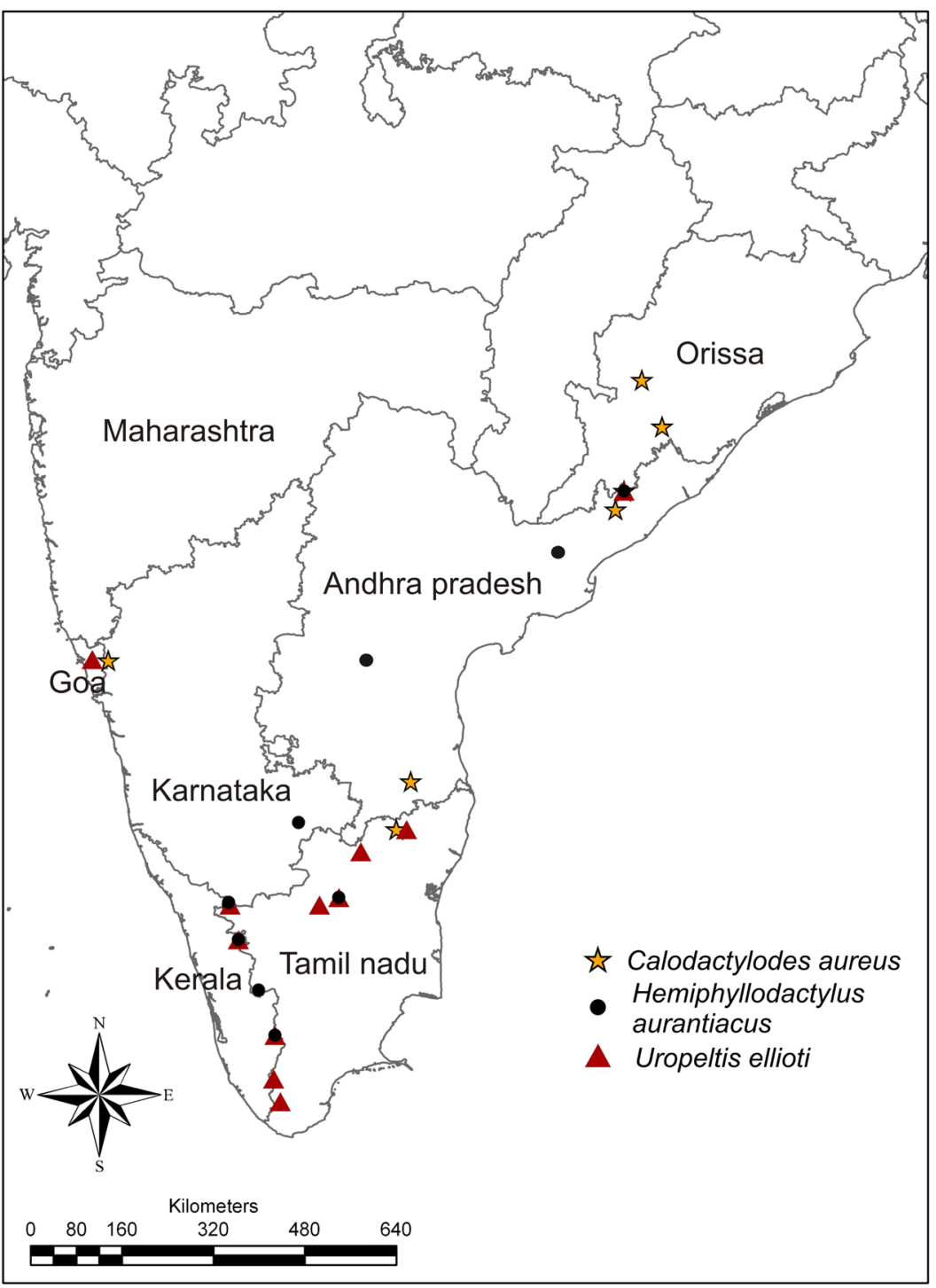

Figure 2. Map showing distribution records for Hemiphyllodactylus aurantiacus, Calodactylodes aureus and Uropeltis ellioti
Das (2000) reported the presence of preanal and femoral pores in males collected from Vellore, Tamil Nadu. Our specimens fit with the descriptions of Smith (1935) and Javed et al. (2007).

Calodactylodes aureus has been reported from Seshachalam and Velikonda ranges of the southern Andhra Pradesh (Daniel et al. 1986); Tirupattur in North Arcot District, Tamil Nadu (Beddome 1870); Niyamgiri Hills, Rayagada and Kalahandi districts of Orissa (Dutta et al. 2005) and Papikonda Hills, northern Andhra Pradesh (Javed et al. 2007). All previous records of Calodactylodes aureus were from much lower elevation: $<50 \mathrm{~m}$ at Balamadi Hill about $5 \mathrm{~km}$ from Vellore Town, Tamil Nadu (Bauer \& Das 2000) and 53m at Papikonda Hills, Andhra Pradesh, (Javed et al. 2007). Present records in Araku Valley at 970m, Andhra Pradesh bordering Orissa, further confirm its northward geographical distribution, and extend the altitudinal distribution of the species up to $1000 \mathrm{~m}$ (Fig. 2). The phylogeny of Calodactylodes may be interesting as it represents one among a few lizard genera strictly endemic to peninsular India and Sri Lanka, indicating a possible Gondwanan origin (Bauer \& Das 2000). Further surveys and molecular studies are required to understand the distribution and phylogeny of this species.

\section{Uropeltis ellioti (Gray, 1845)}

During the present study, an intact specimen of Uropeltis (SVL $252 \mathrm{~mm}$ and TL $10 \mathrm{~mm}$ ) was obtained from Public Works Department personnel (Images 5-6) near Araku Town. It was identified as Uropeltis ellioti based on the following characters; body scales in 17 rows throughout its length, 148 ventral scales, dark brown body powdered with minute yellow spots on the dorsum and larger blotches on the venter, distinct yellow line on the side of the neck, yellow stripe on each side of the tail connected by a transverse bar over the anal region and obliquely truncate tail forming a feebly convex disc with bi, tri- and multi-carinate scales. 
Uropeltis ellioti is reportedly widespread in the hills of Peninsular India from south of Goa gap to Tirunelveli in the Western Ghats and along the Andhra-Orissa border to south of Eastern Ghats (Smith 1943; Rajendran 1985; Whitaker \& Captain 2004) (Fig. 2). Specific locality records include, Shevaroy and Kolli hills, South Arcot, Jalarpet (= Jolarpet) of Tamil Nadu, Visakhapatnam District of Andhra Pradesh and Ganjam in Orissa in the Eastern Ghats (Smith 1943). In the Western Ghats, it has been reported from Manjolai (Tirunelveli), Courtallam and Anaikatty Hills in Tamil Nadu and Sevenmalai Hills, Kerala (Rajendran 1985; Kannan \& Bhupathy 1997). Whitaker \& Captain (2004) noted that Uropeltis elioti is a complex of species endemic to India and urged a closer look at its taxonomy. The present report reaffirms the occurrence of this species in Visakhapatnam area of the Eastern Ghats.

Records of Hemiphyllodactylus aurantiacus, Calodactylodes aureus and Uropeltis ellioti in Araku Valley show our poor understanding on the distribution of fauna, and we recommend further studies in the Eastern Ghats at the earliest opportunity.

\section{REFERENCES}

Bauer, A.M. \& I. Das (1999). The systematic status of the endemic south Indian gecko Hemiphyllodactylus aurantiacus (Beddome, 1870). Journal of South Asian Natural History 4(2): 213-218.

Bauer, A.M. \& I. Das (2000). A review of the gekkonid genus Calodactylodes (Reptilia: Squamata) from India and $\mathrm{Sr}$ Lanka. Journal of South Asian Natural History 5(1): 25-35.

Beddome, R.H. (1870). Description of some new lizards from the Madras Presidency. Madras Monthly Journal of Medical Science 1: 30-35.

Daniels, R.J.R. (1994). Notes on a rare south Indian gecko, Hemiphyllodactylus typus Beddome. Dactylus 2: 132-133.

Daniels, R.J.R. \& N.M. Ishwar (1994). Rarity and the herpetofauna of the southern Eastern Ghats, India. Cobra 16: 2-14.

Daniels, R.J.R. \& M.V.R. Kumar (1998). Amphibians and reptiles of Kolli Hills. Cobra 31: 3-5.
Daniel, J.C., B. Bhushan \& A.G. Sekar (1986). Rediscovery of the golden gecko Calodactylodes aureus (Beddome) in the Eastern Ghats of Andhra Pradesh. Journal of the Bombay Natural History Society 83: 15-16.

Das, I. (2003). Growth of knowledge on the reptiles of India, with an introduction to systematics, taxonomy and nomenclature. Journal of Bombay Natural History 100(2\&3): 446-501.

Dutta, S.K., B. Mohanty \& P.P. Mohapatra (2005). Niyamgiri unraveled. Sanctuary Asia Magazine October: 56-59.

Javed, S.M.M., A. Waran \& F. Tampal (2007). On the occurrence of golden gecko Calodactylodes aureus (Beddome, 1870) in Papikonda Hills, Eastern Ghats, Andhra Pradesh, India. Zoos' Print Journal 22(6): 2727-2729.

Javed, S.M.M., K.T. Rao, C. Srinivasulu \& F. Tampal (2010). Distribution of Hemiphyllodactylus aurantiacus (Beddome, 1870) (Reptilia: Gekkonidae) in Andhra Pradesh, India. Journal of Threatened Taxa 2(1): 639-643.

Kannan, P. \& S. Bhupathy (1997). Occurrence of the Elliot's Shieldtail Snake (Uropeltis ellioti) in Anaikatty Hills, Nilgiri Biosphere Reserve. Cobra 28: 34-35.

Mani, M.S. (1974). Physical Features, pp. 11-59. In: M.S. Mani (ed). Ecology and biogeography in India. Dr. W. Junk B.V. Publishers, The Hague, 725pp.

Mukherjee, D. (2007). Resource utilization patterns of reptiles in the tropical dry mixed deciduous forest of Anaikatty Hills, Western Ghats, India. PhD Dissertation, Bharathiar University, Coimbatore, India, 150pp.

Rajendran, M.V. (1985). Studies in Uropeltid snakes. Madurai Kamraj University, Madurai, 132pp.

Rao, G.V.S. \& G.R. Kumari (2002). Flora of Visakhaptnam, Andhra Pradesh - Vol 1. Botanical Survey of India, MoEF, 612pp.

Rodgers, W.A, H.S. Panwar \& V.B. Mathur (2002). Wildlife Protected Areas in India: A review (Executive Summary). Wildlife Institute of India, Dehradun, 44pp.

Sanyal, D.P., B. Dattagupta \& N.C. Gayen (1993). Reptilia, pp.1-63. In: Ghosh, A.K. (ed.). Fauna of Andhra Pradesh Part - I. State Fauna Series 5, Zoological Survey of India, Calcutta.

Smith, M.A. (1935). The Fauna of British India, including Ceylon and Burma: Reptilia and Amphibia -Vol. II. Sauria. Taylor and Francis, London, 440pp.

Smith, M.A. (1943). The Fauna of British India: Reptilia and Amphibia, including the whole of the Indo-Chinese region Vol. III. Serpentes. Taylor and Francis, London, 583pp.

Whitaker, R. \& A. Captain (2004). Snakes of India: The Field Guide. Draco Books, India, 494pp. 